\title{
Extraction and recovery technique for myxozoan parasites from the Piaractus mesopotamicus kidney embedded in paraffin
}

\author{
Wilson G. Manrique ${ }^{1 *}$ \\ Mayra A. P. Figueiredo ${ }^{1}$ \\ Gustavo S. Claudiano ${ }^{1}$ \\ Mauricio L. Martins ${ }^{2}$ \\ Flávio R. Moraes ${ }^{1}$ \\ ${ }^{1}$ Departamento de Patologia Veterinária, Faculdade de Ciências Agrárias e Veterinárias \\ Universidade Estadual Paulista \\ Via de acesso Prof. Paulo Donato Castellane s/n, CEP 14884-900, Jaboticabal - SP, Brazil \\ ${ }^{2}$ Laboratório de Sanidade de Organismos Aquáticos, Departamento de Aquicultura \\ Universidade Federal de Santa Catarina \\ Rodovia Admar Gonzaga, CEP 88040-900, Florianópolis - SC, Brazil \\ * Corresponding author \\ wilsongomezmanrique@yahoo.es
}

Submetido em 18/06/2013

Aceito para publicação em 01/09/2013

\section{Resumo}

Técnica de extração e recuperação de parasitos myxozoa de rim de Piaractus mesopotamicus incluído em parafina. Tecidos fixados e incluídos em parafina para estudos histopatológicos mantêm suas características celulares. Há vários protocolos de extração de material genético a partir de tecido incluído em parafina, mas não há protocolo para material destinado à identificação direta de parasitos. A falta de técnicas que descrevam a recuperação de parasitos a partir de tecido incluído em parafina fez com que se testasse uma técnica para recuperar mixosporídeos encontrados em fragmentos de rim de P. mesopotamicus incluídos em parafina, para rápida, direta e econômica identificação. Uma vez retirado o excesso de parafina do fragmento de rim, este foi desparafinado em xilol, hidratado em álcool 70\%, colocado em tubo Eppendorf contendo álcool 70\% e deixado sob agitação vigorosa e constante em vórtex até a desintegração do tecido. O material precipitado foi misturado ao álcool $70 \%$ e $20 \mu \mathrm{L}$ foram coletados para confecção de extensões, que foram coradas com Giemsa. Esporos de Myxobolus sp. em vários estágios de desenvolvimento foram observados em microscopia de luz. A técnica mostrou-se útil para recuperação de mixosporídeos a partir de tecido incluído em parafina e constitui uma ferramenta eficaz para estudos de prevalência quando os mixosporídeos não forem detectados em montagens frescas.

Palavras-chave: Myxozoa; Pacu; Parasitologia; Técnica de extração

\section{Abstract}

Tissues fixed and embedded in paraffin for histopathological studies keep their cell characteristics. There are several protocols for extracting genetic material from tissue embedded in paraffin, but there is no protocol for material aimed at the direct identification of parasites. The lack of techniques which describe the recovery of 
parasites from tissue embedded in paraffin has led us to test a technique for recovering myxosporean parasites found in Piaractus mesopotamicus kidney fragments embedded in paraffin, for a rapid, direct, and economic identification. Once the excess paraffin was removed from the kidney fragment, this was deparaffinized in xylene, hydrated in $70 \%$ alcohol, placed in an Eppendorf tube containing $70 \%$ alcohol, and left under vigorous and constant agitation in a vortex until the tissue was disintegrated. The precipitated material was mixed with the $70 \%$ alcohol and $20 \mu \mathrm{L}$ were collected for preparing the smears, which were stained with Giemsa. Myxobolus sp. spores at many developmental stages were observed by light microscopy. The technique has proved to be useful for recovering myxosporean parasites from tissue embedded in paraffin and it constitutes an effective tool for prevalence studies when the myxosporean parasites are not detected in fresh mounts.

Key words: Extraction technique; Myxozoa; Pacu; Parasitology

Protocols for genetic extraction of parasitized tissue fixed in a formalin solution or Bouin and embedded in paraffin were registered by Ribeiro-Silva and Garcia (2008). Despite there is a long list of extraction protocols, few studies consider and describe the reuse of this material for parasite identification. The technique of fixing organs in Bouin and embedding them in paraffin has been replaced by fixing organs in a formalin solution and embedding them in glycol methacrylate, due to improved outcomes in terms of using less artifacts and obtaining a better resolution by light microscopy (COLE, SYKES, 1974; JUNQUEIRA, 1995). However, several laboratories use this technique with paraffin due to economic reasons and easy handling to preserve the morphological cell characteristics, as well as the compatibility to use antibodies in immune histochemical reactions (LEHMANN; KREIPE, 2001).

Myxozoan are among the most important pathogens observed in marine and freshwater fish species which can parasitize many organs, causing economic losses (SARDELLA et al., 1987; CASAL et al.,2002; MORAES; MARTINS, 2004; ESZTERBAUER et al., 2006). They are found free into the cavities (celozoic), within the cells and tissues (histozoic), and into the blood vessels. The main hosts are aquatic vertebrates and, in some cases, invertebrates. Their pathogenicity is related to lesions caused by plasmodia in host tissues (LOM; DYKOVÁ, 1992) or to the production of enzymes which degenerate the tissue (KAWAI et al.,2012). According to Eszterbauer et al. (2006), 52 genera and 1,350 parasitic myxozoan species have been observed. In South America, only 31 species were registered, and 28 species belong to the Myxobolus genus (EIRAS et al., 2008).
Henneguya sp. and Myxobolus sp. (Myxobolidae) are among the most important parasites causing damage to farmed fishes in Brazil (MARTINS et al., 1997;1999a; 1999b; 2002;MORAES; MARTINS, 2004;ADRIANO et al., 2005; 2006; SCHALCH; MORAES, 2005). Identification at the genus level in histological sections may be obtained according to the technique proposed by Manrique et al. (2012) using Ziehl-Neelsen stain or Giemsa in fresh mounts for microscope observation (MEYERS et al., 1977).

Using these techniques allows a posterior observation and identification of spores for morphological and morphometric determination (CAMPOS et al., 2008; 2011). The technique enables identification at the genus level (LOM; NOBLE, 1984). Considering the lack of similar studies, aimed at recovering parasites from organs embedded in paraffin, this study describes a technique for recovering myxozoan parasites from fixed tissue.

A paraffin block with the Piaractus mesopotamicus kidney fixed in a Bouin solution for $6 \mathrm{~h}$ was selected for $5 \mu \mathrm{m}$ thick histological sections and stained with hematoxylin-eosin and Ziehl-Neelsen for histopathological analysis (as approved by the Research Ethics Committee of CEUA/UNESP, under the Protocol 020092/2009). When parasites were observed, the excess paraffin was removed from the block with a scalpel, to get a $3 \times 3 \times 3 \mathrm{~mm}$ cube, to which hot paraffin $\left(60^{\circ} \mathrm{C}\right)$ was added to remove the tissue. After this procedure, the tissue was transferred to Eppendorf $(2.0 \mathrm{~mL})$, then, xylene was added and heated in a bath at $60^{\circ} \mathrm{C}$ for 15 $\min$. The tube was agitated in a vortex for $15 \mathrm{~min}$, centrifuged at $14,000 \mathrm{G}$ for $10 \mathrm{~min}$, and the supernatant 
was discharged. This procedure was repeated twice. We added $2 \mathrm{~mL}$ of $70 \%$ alcohol to the sample and it was agitated in a vortex for $30 \mathrm{~min}$, in order to disintegrate the tissue. Then, the tube was centrifuged at $14,000 \mathrm{G}$ for $15 \mathrm{~min}$ and $20 \mu \mathrm{L}$ of precipitated was collected and mounted between a glass and a cover slip. Other samples were obtained; the smears were stained with Giemsa, they underwent direct observation by light microscopy (Olympus BX51), and the images were registered using a camera DP72 (Software Cell Sens v 1.5).

In the smears, Myxobolus sp. Spores were observed at many developmental stages, as well as polar capsules and nuclei (Figures 1A and 1B).

FIGURE 1: A. Photomicrograph of Myxobolus sp. from the P. mesopotamicus kidney by light microscopy. B. Photomicrograph of Myxobolus sp. from the kidney stained with Giemsa. Bars $=10 \mu \mathrm{m}$.

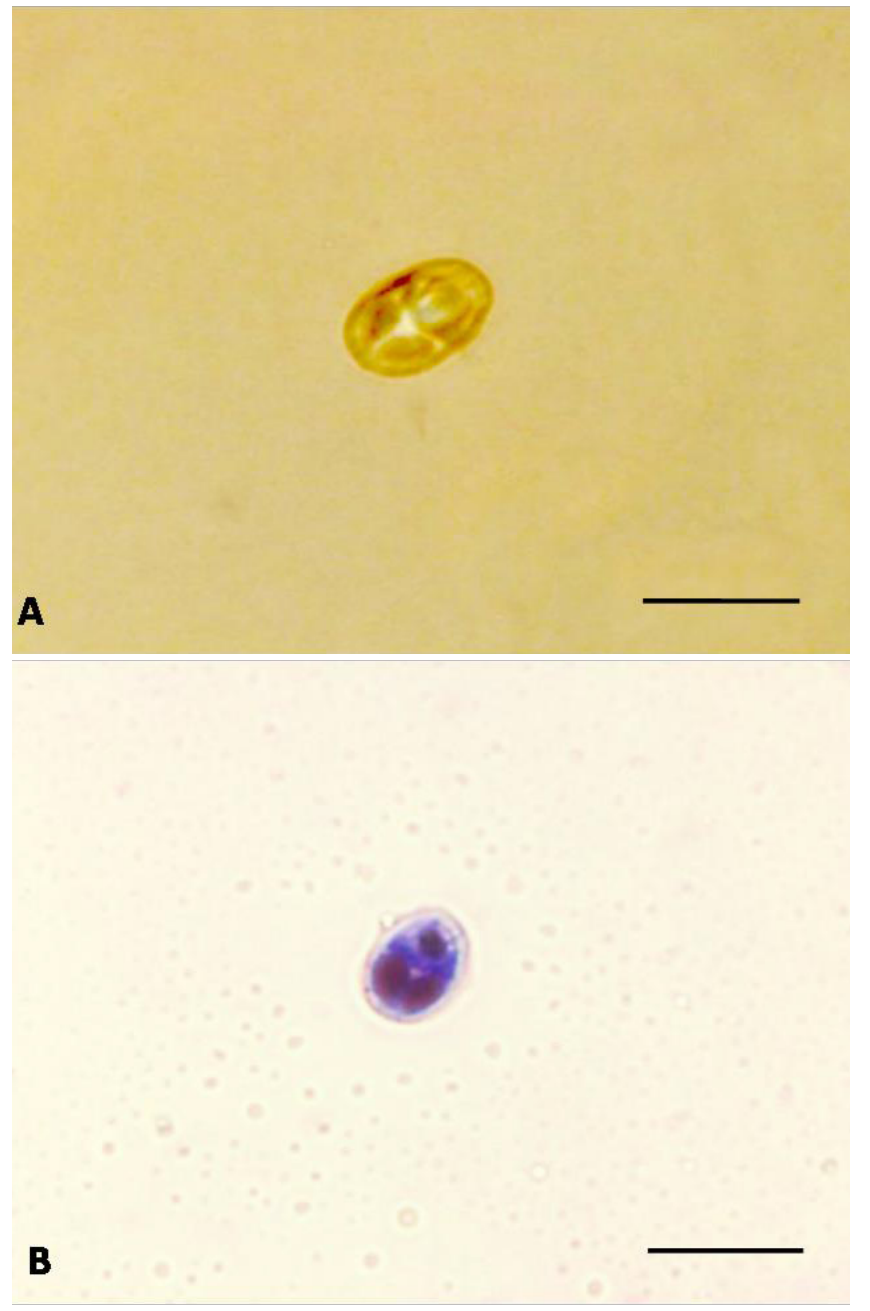

We may conclude that this technique was able to recover the parasite from the tissue embedded in paraffin, allowing the detection of parasites which were not found in fresh mounts.

\section{Acknowledgements}

The authors thank the National Council for Scientific and Technological Development (CNPq), for granting financial support to M.L. Martins and F.R. Moraes, and the Research Support Foundation of the State of São Paulo (FAPESP), for the PhD scholarship granted to W.G. Manrique.

\section{References}

ADRIANO, E. A.; ARANA, S.; CORDEIRO, N. S.Anultrastructural and histopathological study of Hennguyapellucida n. sp. (Myxosporea: Myxobolidae) infectingPiaractus mesopotamicus (Characidae) cultivated in Brazil. Parasite, Les Ulis, v. 12, p. 221$227,2005$.

ADRIANO, E. A.; ARANA, S.; CORDEIRO, N. S. Myxoboluscuneus n. sp. (Myxosporea) infecting the connective tissue of Piaractusmesopotamicus (Pisces: Characidae) in Brazil: histopathology and ultrastructure. Parasite, Les Ulis, v. 13, p. $137-$ $142,2006$.

CAMPOS, C. M.; MORAES, J. R. E.; MORAES, F. R. Histopatologia de fígado, rim e baço de Piaractusmesopotamicus, Prochiloduslineatus e Pseudoplatystomafasciatum parasitados por myxosporídios, capturados no Rio Aquiduana, Mato Grosso do Sul, Brasil. Revista Brasileira de Parasitologia Veterinária, São Carlos, v. 17, p. 200-205, 2008.

CAMPOS, C. M.; MORAES, J. R. E.; MORAES, F. R. Histopathology of gills of Piaractusmesopotamicus (Holmberg, 1887) and Prochiloduslineatus (Valenciennes, 1836) infested by monogenean and myxosporea, caugth in Aquidauana River, State of Mato Grosso do Sul, Brazil. Revista Brasileira de Parasitologia Veterinária, São Carlos, v. 20, p. 67-70, 2011.

CASAL, G.; MATOS, E.; AZEVEDO, C. Ultrastructural data on the spore of Myxobolusmaculatus n. sp. (Phylum Myxozoa), parasite from the Amazonian fish Metynnis maculates (Teleostei). Diseasesof Aquatic Organism, Oldendorf, v. 51, p. 107-111, 2002.

COLE, M. B.; SYKES, S. M. Glycol methacrylate in light microscopy: a routine method for embedding and sectioning animal tissue. Stain Technology, Cambridge, v. 49, p. 387-400, 1974.

EIRAS, J. C.; TAKEMOTO, R. M.; PAVANELLI, G. C. Henneguyacaudicula n. sp. (Myxozoa, Myxobolidae) a parasite of Leporinus lacustris (Osteichthyes, Anostomidae) from the high Paraná River, Brazil, with a revision of Henneguya spp. infecting South American Fish. Acta Protozoologica, Kraków, v. 47, p. 149154, 2008. 
ESZTERBAUER, E.; MARTON, S.; LETENYEI, M.; RÁCZ, O. Z.; LETENYEI, M.; MOLNÁR, K. Morphological and genetic differences among actinosporean stages of fish-parasitic myxosporeans (Myxozoa): difficulties of species identification. Systematic Parasitology, The Hague, v. 65, p. 97-114, 2006.

JUNQUEIRA, L. C. U. Histology revisited - Technical improvement promoted by the use of hydrophilic resin embedding. Ciência e Cultura, São Paulo, v. 47, p. 92-95, 1995.

KAWAI, T.; SEKIZUKA, T.; YAHATA, Y.; KURODA, M.; KUMEDA, Y.; IIJIMA, Y.; KAMATA, Y.; SUGITA-KONISHI, Y.; OHNISHI, T. Identification of Kudoa septempunctata as the causative agent of novel food poisoning outbreaks in Japan by consumption of Paralichthy solivaceus in Raw Fish. Clinical Infectious Diseases, Oxford, v. 54, p. 1046-1052, 2012.

LEHMANN, U.; KREIPE, H. Real-time PCR analysis of DNA and RNA extracted from formalin-fixed and paraffin-embedded biopsies. Methods, Minneapolis, v. 25, p. 409-418, 2001.

LOM, J.; DYKOVÁ, I. Protozoan parasites of fishes. Amsterdam: Elsevier, 1992. 315 p.

LOM, J.; NOBLE, E. R. Revised classification of the class Myxosporea Bütschli 1881. Folia Parasitologica, Praha, v. 3, p. 193-205, 1984.

MANRIQUE, W. G.; CLAUDIANO, G. S.; FIGUEIREDO, M. A. P.; PETRILlO, T. R.; MORAES, J. R. E.; MORAES, F. R. Myxosporidiosis in intensively-reared Piaractus mesopotamicus: histopathological diagnosis by means of Ziehl-Neelsen staining. Pesquisa Veterinária Brasileira, Seropédica, v. 32, n. 11, p. 1133 1137, 2012.

MARTINS, M. L.; ONAKA, E. M.; MORAES, F. R.; BOZZO, F. R.; PAIVA, A. M. F. C.; GONÇALVES, A. Recent studies on parasitic infections of freshwater cultivated fish in the state of São Paulo, Brazil. Acta Scientiarum, Maringá, v. 24, n. 4, p. 981-985, 2002.

MARTINS, M. L.; SOUZA, V. N.; MORAES, J. R. E.; MORAES, F. R. Gill infection of Leporinus macrocepahlus Garavelo et Britiski, 1988 (Osteichthyes: Anostomidae) by Henneguya leporinicola $\mathrm{n}$. sp. (Myxozoa: Myxobolidae): Description, histopathology and treatment. Revista Brasileira de Biologia, São Carlos, v. 59, n. 3, p. 527-534, 1999a.
MARTINS, M. L.; SOUZA, V. N.; MORAES, J. R. E.; MORAES, F. R.; COSTA, A. J. Comparative evaluation of the susceptibility of cultivated fishes to the natural infection with myxosporean parasites an tissues changes in the host. Revista Brasileira de Biologia, São Carlos, v. 59, n. 2, p. 263-269, 1999 b.

MARTINS, M. L.; SOUZA, V. N.; MORAES, J. R. E.; MORAES, F. R.; COSTA, A. J.; ROCHA, U. F. Pathology and behaviour effects associated with Henneguya sp. (Myxozoa: Myxobolidae) infections of captive pacu Piaractus mesopotamicus in Brazil. Journal of World Aquaculture Society, Baton Rouge, v. 28, n. 3, p. 297-300, 1997.

MEYERS, T. R.; SAWYER, T. K.; MADEAN, A. Henneguya sp. (Cnidospora, Myxosporea) in the heart of blue fish, Pomatomus salatrix. Journal of Parasitology, Lawrence, v. 63, p. 890-896, 1977.

MORAES, F. R.; MARTINS, M. L. Condições predisponentes e principais enfermidades de teleósteos cultivados. In: CYRINO, J. E. P.; URBINATI, E. C.; FRACALOSSI, D. M.; CASTAGNOLLI, N. (Ed.). Tópicos especiais em piscicultura de água tropical intensiva. São Paulo: TecAr, 2004. p. 343-386.

RIBEIRO-SILVA, A.; GARCIA, S. B. Estudo comparativo de três diferentes procedimentos para extração de RNA a partir de amostras fixadas em parafina e embebidas em parafina. Jornal Brasileiro de Patologia e Medicina Laboratorial, Rio de Janeiro, v. 44, n. 2, p. 123-130, 2008.

SARDELLA, H. N.; TRINCHERO, L. J.; MANCA, A. E. Efectodel deterioro producido por mixosporídios de la espécie Kudoa rosenbuschi em la musculatura de Merluccius hubbsi. Revista de Investigación y Desarrollo Pesquero, Mar del Plata, v. 7, p. 105112, 1987.

SCHALCH, S. H. C; MORAES, F. R. Distribuição sazonal de parasitos branquiais em diferentes espécies de peixes em pesquepague do município de Guariba SP, Brasil. Revista Brasileira de Parasitologia Veterinária, São Carlos, v. 14, n. 4, p. 141-146, 2005. 